\title{
TRAITS KEPRIBADIAN, SPIRITUALITAS, DUKUNGAN EMOSIONAL PASANGAN DAN PENGARUHNYA TERHADAP KESEJAHTERAAN PSIKOLOGIS IBU PENGHUNI 'SARANG KOSONG' DI KOTA BANDUNG
}

\section{PERSONALITY TRAITS, SPIRITUALITY, MARRIAGE COUPLE EMOTIONAL SUPPORT ON AND THE INFLUENCES FOR PSYCHOLOGICAL WELL-BEING OF EMPTY-NESTER MOTHERS IN BANDUNG}

\author{
Ria Wardani \\ Universitas Kristen Maranatha \\ Email korespondensi : riawardani_p@yahoo.co.id
}

\begin{abstract}
Abstrak
Masa paruh baya adalah saatnya menghadapi fenomena 'sarangh kosong' yaitu rumah tanpa kehadiran anak-anak. Sebagai suatu bentuk transisi kehidupan sekaligus life event, 'sarang kosong' ini merupakan kejadian yang harus diadaptasi, khususnya bagi para ibu. Sebagai suatu proses, adaptasi ini akan melibatkan sumber daya internal (kepribadian dan spiritualitas) maupun eksternal (dukungan emosional pasangan) dan berujung pada terbangunnya kesejahteraan psikologis. Menggunakan desain penelitian causal inferences, seluruh responden yang berukuran 201 diolah datanya dengan menggunakan SEM-PLS. Hasil penelitian membuktikan, secara serempak tidak semua trait kepribadian memberikan sumbangan pengaruh terhadap terbangunnya kesejahteraan psikologis ibu penghuni 'sarang kosong.' Akan tetapi spiritualitas dan dukungan emosional pasangan yang tumbuh setelah trait kepribadian memberikan respon atau tanggapan terhadap keadaan di 'sarang kosong' terbukti memberikan pengaruh terhadap kesejahteraan psikologis yang terbangun. Trait kepribadian dengan sifat-sifat khas yang terangkum di dalamnya perlu ditemukenali dengan baik oleh ibu penghuni 'sarang kosong' untuk kemudian diberdayakan sebagai kekuatan yang handal dalam proses adaptasi di masa transisi.
\end{abstract}

Kata kunci: masa transisi 'sarang kosong', kesejahteraan psikologis, spiritualitas, dukungan emosional, trait kepribadian

\section{Abstract}

Midlife is a time to face the phenomenon of empty nest that is house without the presence of children. As a transitional life forms, empty nest is an event that should be adapted, especially for mothers. As a process, this adaptation will involve internal resources (personality and spirituality) and external (partner's emotional support) and led to the establishment of psychological well-being. Research design causal inferences, the entire size of 201 respondents who processed the data by using SEM-PLS.The research proves, simultaneously not all personality trait contributed influence on the establishment of maternal psychological well-being. But spirituality and emotional support couples who grow after personality trait response to the situation in the empty nest proved to give effect to the psychological well-being awakened. Personality trait with distinctive properties are summarized to be identified properly by the mother occupants empty nest for later empowered as a reliable force in the process of adaptation in the transition period.

Keywords : emptynest, psychological well-being, spirituality, emotional support, personality trait

\section{Pendahuluan}

Data dari pelbagai negara di belahan dunia mengonfirmasi gambaran kian bertambahnya populasi paruh baya dan lanjut usia di abad ke 21 dengan kondisi yang lebih sehat dan lebih produktif. Kenyataan ini merupakan akibat langsung dari gaya hidup sehat dan temuan-temuan di bidang kedokteran yang membantu umat manusia memerlambat proses penuaan, sehingga batas usia paruh baya dapat didorong ke atas (Santrock, 2013).

Usia paruh baya merupakan periode perkembangan yang dimulai sekitar 40 hingga 45 tahun dan berakhir sekitar 60 hingga 65 tahun, banyak ditandai oleh penurunan keterampilan fisik dan meluasnya tanggung jawab yang merepresentasikan konsep gains (pertumbuhan) dan losses (penurunan) secara seimbang. Mengacu pada the contemporary life-span approach (Luchman dkk, 2002; Schwarzer \& Luszezynska, 2013 dalam Santrock, 2013) ada beragam kejadian dalam perjalanan rentang kehidupan individu, termasuk yang berkategori transisi. Salah satunya adalah masa transisi 'sarang kosong' yang berlangsung saat periode perkembangan paruh baya. Fenomena 'sarang kosong' (empty nest) ditandai dengan kepergian anak-anak dari rumah, baik untuk alasan sekolah/pendidikan, pekerjaan, pernikahan, maupun gaya hidup sehingga menyisakan orangtua di rumah tanpa kehadiran anak-anaknya.

Sebagaimana lazimnya berada pada masa transisi kehidupan yang setara dengan life-events, keadaan rumah tanpa kehadiran anak-anak merupakan kejadian yang harus diadaptasi, tidak terkecuali oleh para ibu. Sekalipun masa transisi 'sarang kosong' merupakan peristiwa yang telah dapat diantisipasi jauh sebelumnya, namun manakala seseorang benar-benar berada dalam situasi nyata maka pelbagai mekanisme psikologis akan berlangsung di dalamnya sebagai upaya menanggapi keadaan transisi ini. Bagaimana seorang ibu penghuni 'sarang kosong' memberikan tanggapan atas masa transisi ini akan ditentukan oleh peubahpeubah yang memediasinya, baik yang bersumber dari internal maupun dari lingkungan eksternal individu. Tanggapan ini, secara menyeluruh, merepresentasikan proses adaptasi. 
Adaptasi merupakan proses yang akan berlangsung terus-menerus dengan melibatkan beragam sumber daya individu, baik internal maupun eksternal dan akan berujung pada tercapainya kesejahteraan psikologis. Sumber daya internal dalam penelitian ini adalah kepribadian dan spiritualitas, sedangkan sumber daya eksternal adalah dukungan emosional pasangan.

Terdapat beragam teori kepribadian yang relevan dengan individu paruh baya dan lanjut usia, satu diantaranya adalah Trait Models dari Costa and McCrae (2003) yang disebut The Five-Factor Model, di dalamnya terdiri atas lima dimensi yaitu (1) neuroticism, (2) extraversion, (3) openness to experience, (4) conscientiousness, dan (5) agreeablenes. Alasan memilih teori ini, karena trait model berfokus pada sifat-sifat mental, emosional, temperamental, dan perilaku, atau atribut. Model traits ini, mereduksi kepribadian dan perilaku menjadi elemen-elemen dasar, dan berasumsi bahwa traits secara nyata merediksi perilaku individu.

Kajian konseptual tentang spiritualitas mengantarkan penulis pada model spiritualitas holistik dari Rovers \& Kocum (2010). Dinyatakan bahwa model holistik dari spiritualitas memosisikan spiritualitas pada ruang multidimensional (Larson, Sawyer, \& McCullough, 1997 dalam Rovers \& Kocum, 2010). Spiritualitas dapat dipahami sebagai kekuatan pendorong yang memberikan makna, stabilitas, dan tujuan hidup melalui keterhubungan dengan dimensi yang melebihi diri (transcend the self) (Harmon, 1985; Oldnal, 1996; Reed, 1992 dalam Rovers \& Kocum, 2010). Dimensi-dimensi itu bisa berupa keberadaan Tuhan, alam, teman, keluarga, dan komunitas. Pandangan holistik mengantarkan penulis pada upaya mendeduksikan spiritulitas sebagai penggabungan antara dimensi Ketuhanan dan dimensi Hubungan dengan sesama, sebagai manifestasi spirit dari kehidupan religi yang telah tertanam dalam diri individu sejak usia dini. Adapun faktor-faktornya adalah keyakinan terhadap Tuhan (mengisi dimensi vertikal); pencarian makna dan tujuan hidup, hubungan dengan orang lain, dan perasaan aman (mengisi dimensi horizontal).

Ketersediaan dukungan sosial merupakan satu diantara sekian banyak fungsi hubungan sosial. Struktur jejaring sosial ini dapat digambarkan sebagai karakteristik dyadic dan berdasarkan karakteristik jejaring secara menyeluruh (Israel, 1982; House, Umberson, dan Landis, 1988 dalam Heaney dan Barbara 2008). Jejaring sosial memiliki banyak fungsi sosial: sebagai pengaruh sosial, kontrol sosial, social undermining, perbandingan sosial, pertemanan, dan dukungan sosial. Menurut seminal work oleh House (1981), dukungan sosial adalah konten fungsional dari hubungan yang dapat dikelompokkan ke dalam empat tindakan atau perilaku dukungan, yaitu dukungan emosional, dukungan instrumental, dukungan penghargaan, dan dukungan informasional.

Dalam konteks hubungan akrab (close relationships) dan bersifat dyadic, dukungan emosional pasangan menjadi sumber kekuatan eksternal yang signifikan bagi proses adaptasi ibu penghuni 'sarang kosong.' Dukungan emosional dalam bentuk pemahaman, penghargaan, dan kepedulian yang diekspresikan oleh pasangan terhadap ibu emptynester merupakan sumber daya eksternal yang akan memediasi traits kepribadian untuk membantu ibu empty-nester meraih kesejahteraan psikologisnya.

\section{Model Penelitian}

Masa transisi 'sarang kosong' dapat dikategorikan sebagai life-events. Sebagai life-event, masa transisi ini akan memeroleh respon atau tanggapan dari para ibu yang mengalaminya. Respon atau tanggapan yang diberikan merupakan bagian dari faktor yang memediasi life-events, yaitu kepribadian, spiritualitas, dan dukungan emosional pasangan. Interaksi antara life-event dan faktor-faktor yang memediasi merupakan manifestasi dari proses adaptasi. Luaran dari proses adaptasi ini adalah kesejahteraan psikologis. Seorang ibu penghuni 'sarang kosong' yang sejahtera secara psikologis di dalam life-event-nya mengindikasikan orang dewasa yang berubah dan bertumbuh secara berkesinambungan.

Upaya meraih kesejahteraan memerlukan pelibatan beragam sumber daya individual, internal maupun eksternal. Dalam model penelitian ini, sumber daya internal individu adalah trait kepribadian, melalui teori the big five factors of personality dari Costa \& McCrae; spiritualitas atau kekuatan spirit yang meyakini pentingnya keterhubungan dengan sesuatu yang sakral/ suci dan hubungan baik dengan sesama atau alam sekitar yang didasarkan pada keyakinan religi pada diri setiap ibu penghuni 'sarang kosong.' Trait kepribadian dan spiritualitas dalam penelitian ini diposisikan sebagai sumber daya internal. Adapun dukungan emosional pasangan diposisikan sebagai sumber daya eksternal.

Kesejahteraan psikologis menurut tradisi filosofis eudaimonia dari Ryff, berfokus pada bagaimana individu mengembangkan segenap potensi yang dimiliki sebagai manifestasi dari pribadi yang terus bertumbuh, selanjutnya dipandang sebagai indikator penting dari keberfungsian positif (Diaz, RodriguezCarjaval, Blanco et al., 2006 dalam Wells (Ed.) 2010). Perkembangan potensi-potensi yang mengisyaratkan pertumbuhan pribadi berkelanjutan di atas, terukur melalui model multidimentionalitas. Di dalam model multidimensional terdapat enam dimensi berbeda, yaitu self-acceptance, personal growth, positive relations with others, environmental mastery, purpose in life, dan autonomy.

Sebagaimana lazimnya, individu yang tengah mengalami masa transisi kehidupan memerlukan kekuatan untuk beradaptasi. Kutipan dari Papalia et al., (2007) menyatakan bahwa mekanisme adaptasi terhadap pelbagai keadaan dalam kehidupan merupakan fungsi penting dari kepribadian. Kepribadian akan merespon beragam kejadian dalam kehidupan, sehingga menjadi kunci mendasar yang akan membantu seseorang beradaptasi terhadap kejadian-kejadian, keadaan-keadaan, dan kondisikondisi kehidupan (Papalia et al., 2007).

Trait kepribadian menurut model the big five factor, terdiri atas lima yaitu openness, conscientiousness, extraversion, agreeableness, dan neuroticism. 
Pada dasarnya, setiap orang memiliki kelima trait tersebut, namun pembedanya terletak pada kekuatan atau kelemahan setiap trait yang dihayati. Ke lima traits kepribadian yang bertindak sebagai disposisi individual, akan merespon setiap keadaan dengan sifatsifat khas yang terangkum di dalamnya. Kemudian dalam kerangka proses adaptasi akan berdinamik dengan spiritualitas, dan dukungan emosional pasangan sehingga menghasilkan luaran berupa terbangunnya kesejahteraan psikologis ibu penghuni 'sarang kosong.' Spiritualitas dan dukungan emosional pasangan diposisikan sebagai peubah intervening atau seringkali disebut mediator, yang berarti setiap variasi pada traits kepribadian akan menyebabkan variasi pada spiritualitas (di satu sisi) dan variasi dukungan emosional (di sisi lain) yang kemudian akan memengaruhi variasi dalam kesejahteraan psikologis.

Berdasarkan paparan di atas, konstruk dalam model kersejahteraan psikologis ibu penghuni 'sarang kosong' terbangun sebagai berikut:

\section{Metode}

Penelitian ini akan mengkaji kesejahteraan psikologis ibu penghuni 'sarang kosong' yang dipengaruhi traits kepribadian, spiritualitas, dan dukungan emosional pasangan. Agar peubah-peubah yang akan diteliti mampu menjawab pertanyaan penelitian, desain penelitian yang akan digunakan adalah causal inferences, yaitu menemukan penjelasan tentang interaksi antara trait kepribadian dengan spiritualitas dan pengaruhnya terhadap kesejahteraan psikologis ibu penghuni 'sarang kosong'; dan traits kepribadian berinteraksi dengan dukungan emosional pasangan dilihat pengaruhnya terhadap kesejahteraan psikologis ibu penghuni 'sarang kosong'.

Spiritualitas dan dukungan emosional pasangan diposisikan sebagai variabel intervening atau sering disebut sebagai mediator yang dikonseptualisasikan sebagai mekanisme yang akan dilalui oleh variabel bebas (trait kepribadian) dalam memengaruhi variabel

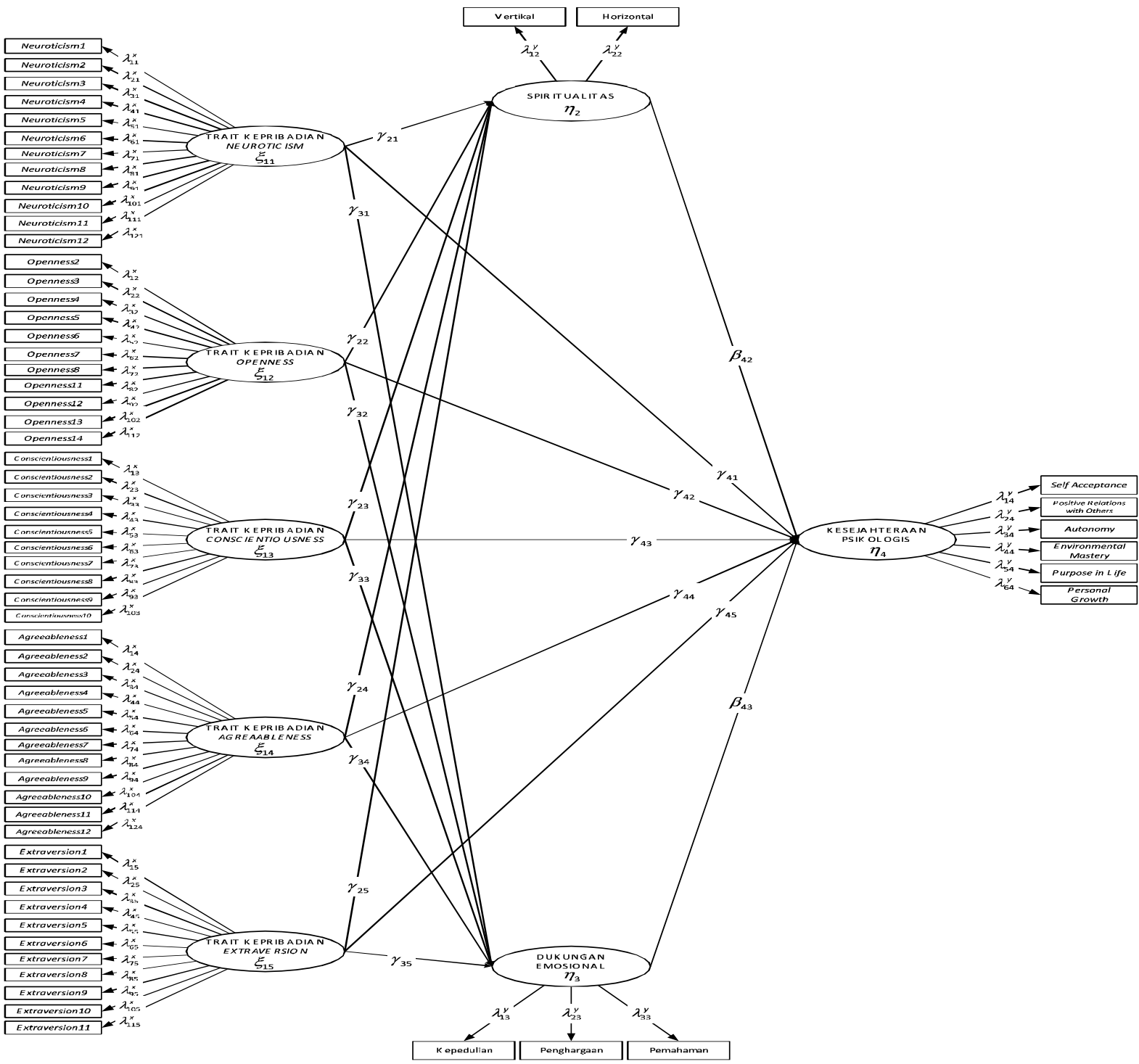


terikat (kesejahteraan psikologis) (Hayes, 2013). Ini berarti, setiap variasi yang terjadi pada variabel bebas (trait kepribadian) akan menyebabkan variasi pada satu atau lebih mediator, yang kemudian akan mempengaruhi variasi pada kesejahteraan psikologis (variabel terikat).

Ukuran sampel dalam penelitian adalah 201 responden, terdiri atas ibu yang anak-anaknya sudah tidak tinggal serumah lagi dan masih memiliki pasangan (suami). Teknik analisis data yang digunakan adalah PLS-SEM. PLS-SEM bekerja efektif dengan ukuran sampel yang kecil, model yang kompleks, dan tidak memiliki asumsi mengenai data yang mendasarinya. Selain itu, PLS-SEM dengan mudah dapat menangani model pengukuran reflektif dan formatif.

\section{Hasil dan Pembahasan}

Berdasarkan hasil pengujian SEM-PLS, diperoleh bukti bahwa secara serempak trait neuroticism, openness, cionscientiousness, dan extraversion memberikan pengaruh signifikan terhadap terbangunnya kesejahteraan psikologis ibu penghuni 'sarang kosong.' Sedangkan trait agreeableness tidak memberikan pengaruh terhadap kesejahteraan psikologis partisipan.

Trait openness dan agreeableness terbukti memberikan pengaruh terhadap spiritualitas, sedangkan trait neuroticism, conscientiousness, dan extraversion tidak terbukti memengaruhi spiritualitas. Trait agreeableness dan extraversion memberikan pengaruh terhadap dukungan emosional pasangan, sedangkan trait neuroticism, openness, dan conscientiousness tidak terbukti memengaruhi dukungan emosional pasangan.

Spiritualitas dan dukungan emosional pasangan memengaruhi kesejahteraan psikologis secara signifikan. Berdasarkan muatan faktornya, dimensi kesejahteraan psikologis yang terbukti direfleksikan melalui keenam dimensinya sebagai indikator pengukurnya. Dalam hal ini dimensi personal growth memerlihatkan indikator paling dominan, disusul purpose in life, dan environmental mastery. Gambar hasil pengujian tertera di bawah ini:

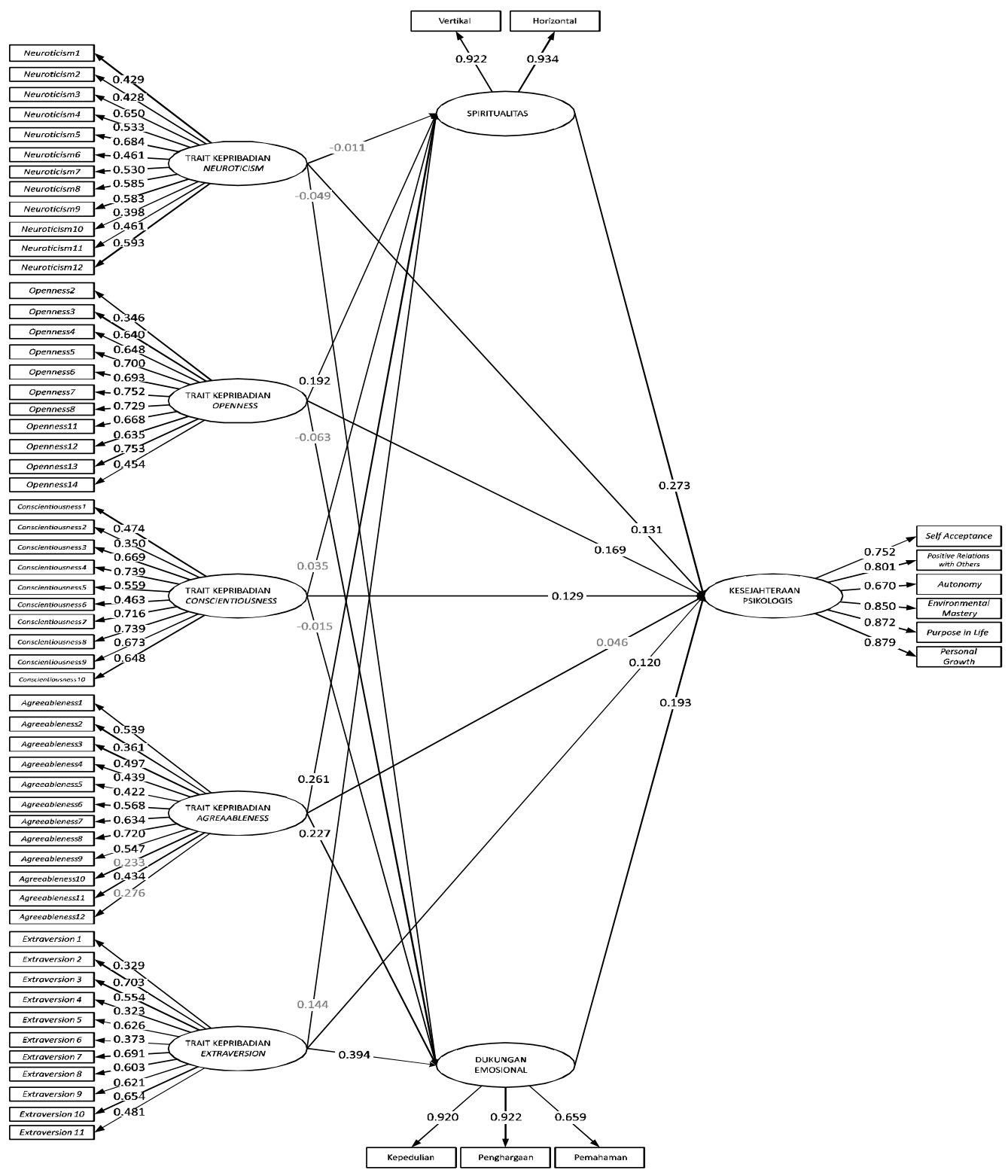


Ibu penghuni 'sarang kosong' dengan sifat-sifat temperamental, penuh kekhawatiran, emosional, dan rentan dalam menghadapi beragam situasi di 'sarang kosong' masih dimungkinkan membangun kesejahteraan psikologisnya khususnya untuk menjadi pribadi yang ingin bertumbuh ditengah-tengah situasi menekan atau tidak menguntungkan. Setidaknya bukti ini menunjukkan bahwa sekalipun diliputi oleh kecemasan dan ketidakstabilan emosi, partisipan masih mampu berpikir jernih bagi kepentingan dirinya sendiri, dalam upayanya beradaptasi ditengah-tengah keadaan 'sarang kosong.' Akan tetapi sifat-sifat temperamental tidak dengan serta-merta mendorong partisipan untuk menggantungkan dirinya kepada sesuatu yang diyakininya sebagai kekuatan sakral maupun kepada orang lain. Demikian pula sifat-sifat temperamental dan penuh rasa khawatir ini tidak mengundang pasangan untuk memberikan kepedulian, pemahaman, dan penghargaan yang empatetik. Kenyataan ini dapat dipahami mengingat ibu dengan trait neuroticism lebih banyak berkutat dengan pikiran dan perasaan negatifnya, sehingga apapun bentuk dukungan yang diberikan pasangannya akan dimaknakan secara tidak relevan.

Trait openness yang berisi sekumpulan sifat imajinatif, kreatif, penyuka perubahan, dan penuh rasa ingin tahu memengaruhi kesempatan partisipan untuk membangun kesejahteraan psikologis, khususnya untuk menjadi pribadi yang terus bertumbuh dengan mewujudkan minat dan potensi diri untuk mengisi kehidupan sehari-hari. Partisipan dengan sifat imajinatif dan penyuka perubahan ini agaknya menjadikan spiritualitas sebagai kekuatan yang akan membantunya beradaptasi terhadap beragam keadaan kehidupan, khususnya dalam masa transisi 'sarang kosong.' Disisi lain, sifat-sifat imajinatif dan kreatif ini mendorong pasangan untuk memberikan dukungan yang signifikan. Kemungkinan karena partisipan tidak membutuhkannya atau karena pasangan menilai partisipan dengan sifat-sifatnya ini memiliki kecakapan memadai untuk mengatasi keadaan sehingga keberadaan dukungan emosional tidak diperlukan.

Ibu penghuni 'sarang kosong' dengan trait conscientiousness yang penuh dengan sifat-sifat teratur, pekerjakeras, disiplin, tekun, dan dipenuhi ambisi-ambisi mampu mengekapresikan potensipotensi yang dimiliki untuk membangun kesejahteraan psikologisnya, khususnya menjadi individu yang dipenuhi keinginan untuk melakukan dan berbuat terbaik bagi kepentingannya di 'sarang kosong.' Inisiatif yang dimiliki ini menjadikan partisipan tidak menjadikan spiritualitas sebagai tumpuan utamanya. Begitupun dukungan emosional dari pasangan bukan menjadi penentunya dalam beradaptasi di 'sarang kosong.' Sifat-sifat yang memampukan partisipan untuk bertindak dan berbuat ditengah-tengah keadaan 'sarang kosong' ini tidak mendorongnya untuk bergantung pada spiritualitas maupun dukungan emosional pasangan.

Trait agreeableness dengan sekumpulan sifat-sifat toleran, diam-diam memilih berdamai dengan keadaan, baik hati dan lembut hati bukanlah sifat yang akan membantu partispan dalam membangun kesejahteraan psikologisnya. Partisipan dengan sifatsifat ini lebih memilih untuk berdamai dengan keadaan, bersikap sabar, dan membiarkan kejadian mengalir begitu saja. Sifat-sifat lembut dan baik hati ini membuatnya fokus untuk membangun kehidupan spiritualitas, yaitu menumbuhkan keyakinan yang kuat bahwa manusia senantiasa berada di bawah kekuasaan yang sakral dan meyakini pentingnya membina hubungan baik dengan sesama juga dengan memelihara lingkungan di sekitarnya. Tidak heran bila sifat-sifat ini menumbuhkan simpati pasangan, sehingga terdorong untuk mengeskpresikan dukungan emosional yang simpatik berupa kepedulian, penghargaan, dan pemahaman.

Trait extraversion yang merupakan kumpulan sifatsifat aktif, suka bersenang-senang, senang berkumpul bersama-sama orang lain, dan menjalani kehidupan dengan bersemangat akan memengaruhi kesejahteraan psikologis yang terbangun. Melalui sifatsifat yang dimilikinya itu partisipan memiliki keinginan untuk menampilkan minat dan keterampilannya dalam menyiasati kehidupan di 'sarang kosong.' Sifat-sifat yang dimiliki itu mengundang respon positif dari pasangan untuk menampilkan penghargaan, pemahaman, dan kepedulian sehingga bersama-sama mengisi kehidupan di 'sarang kosong' dengan kegiatan yang bermakna serta terbina kesaling-pengertian di antara keduanya. Tetapi sifat-sifat aktif dan bersemangat menjalani kehidupan yang dimiliki partisipan tidak berpengaruh terhadap kehidupan spiritualitasnya. Kenyataan ini dimungkinkan karena partisipan lebih memilih untuk mengisi kesehariannya dengan menjalin kebersamaan yang melibatkan orang lain, sehingga spiritnya untuk mendekatkan diri kepada sesuatu yang sakral menjadi berkurang.

Spiritualitas yang mewarnai kehidupan ibu penghuni 'sarang kosong', secara menyeluruh, tumbuh menjadi kekuatan yang membangun kesejahteraan psikologisnya. Demikian pula dengan dukungan emosional pasangan yang turut menjadi kekuatan bermakna dalam membangun kesejahteraan psikologis di dalam 'sarang kosong.' Kedua temuan ini membuktikan bahwa model dalam konstruk kesejahteraan psikologis ibu penghuni 'sarang kosong' turut ditentukan oleh spirit yang bertumbuh dari kekuatan religi yang memang telah tertanam sejak usa dini disamping keberadaan dukungan eksternal yang berasal dari pasangan berupa penghargaan, pemahaman, dan kepedulian yang disampaikan secara nyata. Di bawah disposisi trait kepribadian yang mengawali respon atau tanggapan partisipan terhadap beragam keadaan (menyenangkan atau tidak menyenangkan) di 'sarang kosong,' spiritualitas dan dukungan emosional pasangan bertumbuh menjadi kekuatan yang terlibat dalam beradaptasi dengan keadaan sehingga menghasilkan luaran kesejahteraan psikologis.

\section{Simpulan}

Secara serempak trait neuroticism dan agreeableness tidak memengaruhi terbangunnya kesejahteraan psikologis ibu penghuni 'sarang kosong.' 
Ini artinya sifat-sifat ibu yang cenderung berdamai dengan keadaan, toleran, menyikapi keadaan 'sarang kosong' dengan baik dan lembut hati kecil peluangnya untuk membangun kesejahteraan psikologis karena menerima kedaaan apa adanya tanpa keinginan untuk mengubah atas dasar inisiatif pribadi.

Secara serempak, trait conscientiousness dan extraversion tidak menggerakkan terbangunnya kehidupan spiritualitas ibu penghuni 'sarang kosong.' Ini artinya spirit untuk bertumpu pada kekuatan yang sakral dan hubungan dengan orang lain maupun sesama mahluk ciptaan-Nya tidak kondusif bertumbuh pada ibu penghuni 'sarang kosong' yang aktif dan disiplin penuh keteraturan dan terencana dalam mengisi kehidupan.

Secara serempak trait neuroticism, openness, dan conscientiousness tidak menggerakkan pasangan untuk memberikan dukungan emosional berupa kepedulian, penghargaan, dan pemahaman. Kalaupun secara nyata pasangan mengekspresikan dukungan tersebut, penafsiran ibu penghuni 'sarang kosong' tidak memandangnya sebagai dukungan yang memberikan makna bagi proses adaptasi di 'sarang kosong.'

Kehidupan spiritualitas dan dukungan emosional pasangan menguatkan terbangunnya kesejahteraan psikologis ibu penghuni 'sarang kosong.' Ini artinya setelah trait kepribadian memberikan respon atau tanggapan sebagai bagian dari proses beradaptasi dalam keadaan 'sarang kosong', spirit atas keyakinan akan adanya kekuatan yang sakral termasuk keterhubungan dengan sesama mahluk ciptaan-Nya termasuk dukungan emosional pasangan menjadi kekuatan tersendiri bagi terbangunnya kesejahteraan psikologis ibu penghuni 'sarang kosong.' Adapun dimensi kesejahteraan psikologis yang cenderung menguat adalah keinginan untuk menjadi pribadi yang terus bertumbuh, menatap kedepan untuk meraih tujuan-tujuan yang bermakna, serta mengoptimalkan kemampuan untuk menguasai keadaan pasca anakanak tidak lagi tinggal serumah.

Mengingat dalam kapasitasnya masing-masing setiap trait memberikan atau tidak memberikan pengaruh terhadap kesejahteraan psikologis ibu penghuni 'sarang kosong,' saran yang dapat diajukan adalah sebaiknya partisipan menemukenali dengan baik trait dominan yang menggerakkannya dalam proses adaptasi di 'sarang kosong.' Pengenalan ini akan bermakna sebagai sumber daya yang pada akhirnya akan membantu menyesuaikan diri terhadap beragam keadaan di 'sarang kosong.' Artinya, yang terpenting adalah bagaimana trait itu diberdayakan dan dikelola secara konstruktif bukan ditekan atau diabaikan keberadaannya.

\section{Daftar Pustaka}

Hayes, Andrew F. (2013). Introduction to Mediation, Moderation, and Conditional Process Analysis: A Regression-Based Approach. A chapter excerpt from Guilford Publications.

Heaney, Chaterine A., Israel, Barbara. (2008). Social networks and social support.

In Glanz, Karen., Rimers, Barbara K., Vismannath, K (Eds.). Health Behavior and Health Education: Theory, Research, and Practice Fourth Edition.

McCrae., Robert R and Paul T. Costa, Jr. (2003). Personality in adulthood. A Five-Factor Theory Perspective. Second Edition. New York: The Guilford Press. A Division of Gulford Publications, Inc.

Papalia, Diane E., et al. (2007). Adult development and Aging. Third Edition. New York: The McGraw-Hill Company, Inc.

Rovers, Martin; Lucie Kocum. (2010). Development of a holistic model of spirituality. Journal of Spirituality in Mental Health, 12.2-24.

Santrock, John W. (2013). Life-span development. Ninth Edition. New York: The McGraw-Hill Company, Inc.

Wells, Inggrid E. (Ed). 2010. Psychlogical Well-Being. new York: Nova Science Publisher, Inc. 